Cahiers $d u$ MONDE RUSSE

\section{Cahiers du monde russe}

Russie - Empire russe - Union soviétique et États indépendants

$52 / 1 \mid 2011$

Varia

\title{
Attitudes towards Jews in Odessa: From Soviet rule through Romanian occupation, 1921-1944
}

Les comportements envers les juifs d'Odessa: De la domination soviétique à

l'occupation roumaine, 1921-1944

\section{Diana Dumitru}

\section{(2) OpenEdition}

Journals

Édition électronique

URL : https://journals.openedition.org/monderusse/9324

DOI : 10.4000/monderusse. 9324

ISSN : $1777-5388$

Éditeur

Éditions de l'EHESS

Édition imprimée

Date de publication : 5 mars 2011

Pagination : 133-162

ISBN : 978-2-7132-2351-8

ISSN : $1252-6576$

Référence électronique

Diana Dumitru, «Attitudes towards Jews in Odessa: From Soviet rule through Romanian occupation, 1921-1944 », Cahiers du monde russe [En ligne], 52/1 | 2011, mis en ligne le 28 mars 2014, consulté le 02 septembre 2022. URL : http://journals.openedition.org/monderusse/9324 ; DOI : https://doi.org/ $10.4000 /$ monderusse. 9324

Ce document a été généré automatiquement le 2 septembre 2022

Tous droits réservés 


\title{
Attitudes towards Jews in Odessa: From Soviet rule through Romanian occupation, 1921-1944
}

\author{
Les comportements envers les juifs d'Odessa: De la domination soviétique à \\ l'occupation roumaine, 1921-1944
}

Diana Dumitru

1 The USSR vanished at the turn of the 1990s, but the debates about the "Soviet experiment" and its puzzling legacy are more alive than ever. Since its collapse, an army of social scientists has closely studied the Soviet Union's various facets, attempting to distinguish between the utopian state's real and the declared transformation. The distinctive form of nationalism promoted in the Soviet state has been a permanent object of academic interest and led to various contradicting interpretations of intended goals and achieved results.

2 An older historiographical trend has explained Soviet nationality policy through the "prison of the peoples" paradigm, by emphasizing the regime's repressive policies, arbitrary rules, and the internal borders imposed on its "captive" nations. ${ }^{1} \mathrm{~A}$ recent school of thought, best represented by Terry Martin's "affirmative action empire" model, has stressed the center's "give-and-take" policies in its relationship with national minorities during the 1920s and 1930s, and depicted an interactive and participatory "state-sponsored evolutionism" which resulted from the fusion of a practical desire to avoid the mistakes of previous colonialist nationality policies and the idealistic aim to create a new, "modern" society - a union of completely equal nations, but accepting of difference in a cultural sense. ${ }^{2}$ Significant research has approached the transformative side of Soviet nationality policies, underlying the limits of the Soviet state's intervention and the unintentional emergence and survival of nationalism. ${ }^{3}$ Yet, among this impressive body of literature, virtually no research has assessed the degree to which these newly promoted norms and ideals were absorbed by members of society. ${ }^{4}$ 
3 It is clear, at least in words, that the Soviet state regularly declared its strong commitment to the eradication of national discrimination and its intention to build a society where "the friendship of peoples" would prevail. ${ }^{5}$ Martin admits that ethnic prejudice and conflict declined in the interwar Soviet Union, ${ }^{6}$ while David Hoffman's study points towards the ambiguity of the issue of internalization of the Soviet morals, stressing the diversity of responses provided by the Communist Party members towards Stalinist cultural values. ${ }^{7}$

4 This paper aims to explore the ability of Soviet citizens to internalize state policies focusing on interethnic relations, and this is achieved through a case study assessing how Soviet nationality policies dealt with one of the oldest and intense animosities that existed on its territory: antisemitism. Throughout Russian history, antisemitism has been among the most widespread, violent, and resilient forms of hatred towards a people, and it therefore acts as a particularly difficult problem to solve for the state. If Soviet policies could be seen as successful in this case, it would go a long way towards demonstrating a broader Soviet ability to penetrate its citizenry with fresh values unknown in the Tsarist era. The detailed information and eyewitness testimonies required for such an analysis must be gathered in a small area for analysis to be rigorous. In this context, Odessa makes a suitable subject.

5 Odessa's relevance relates to its significant Jewish population, the ethnic diversity of its residents, and to its status as a city known for its antisemitic violence. ${ }^{8}$ By the number of its victims, the pogrom of 1905 in Odessa surpassed any previous pogrom that took place in Tsarist Russia. ${ }^{9}$ This paper aims to trace the evolution of the relationship between Jews and gentiles in Odessa from the late imperial period to the years of Soviet rule and the occupation of Odessa during the Second World War. The period of Romanian occupation has been chosen as a setting in which the Soviet regime's "achievements" in its fight against antisemitism were put to a severe test since Romania participated in the Holocaust and encouraged the gentile population to betray its Jewish neighbors. As this is a case study on a small territory within the Soviet Union, any conclusion must necessarily be cautious. Nevertheless, if we can observe changes in interethnic behavior under such difficult conditions as antisemitism within Ukraine, it could be suggestive for the rest of the Soviet space.

6 The core material used in this study comes from more than 80 testimonies housed at the Yad Vashem Archives in Jerusalem. These represent audio, video, and written accounts of Odessan Jews, born predominantly between 1900 and 1930, who experienced the Second World War, and later emigrated to Israel. The video and audio interviews were conducted in Israel by Yad Vashem staff between 1952 and 2000, the main goal being to collect individuals' experiences of the Holocaust, and occasionally their description of Jewish life in the prewar years. ${ }^{10}$

\section{The issue of antisemitism in the USSR prior to and during the occupation}

\section{The Soviet fight against antisemitism}

7 When the Communists came to power at the end of the civil war, they were determined to resolve Imperial Russia's long-standing "national question," and this included the problem of rampant antisemitism. A radical new set of policies was instituted, which 
aimed to combat antisemitism and integrate Jewish life into the Soviet economy and society. ${ }^{11}$ The fight against antisemitism was organized on various fronts: religious, political, economic, and social. ${ }^{12}$ For the first time in the history of the Russian state, the Jews received the right to accede to the structures of power and governance.

Under these new conditions, numerous prominent Jews made their way to the summit of Soviet power; even more Jews became prominent figures of Soviet culture and science. By 1927, the entrance of the Jews into the civil service had reached such proportions that the percentage of Jews holding government posts in the now-obsolete Pale of Settlement region was roughly four times their percentage of the population. ${ }^{13}$ More generally, there were significant changes in the mode of employment of Jewish labor during this period. Data suggest that in Ukraine, the Jews, who constituted only 5.4 percent of the population, were disproportionately employed as industrial workers (40 percent), as administrators (20.7 percent), and in the commercial sector (14.9 percent). The fact that commerce accounted for only 14.9 percent of employed Jews meant a substantial reduction from prerevolutionary times, when as many as one-half of all employed Jews worked in small businesses and as artisans. ${ }^{14}$

Second, the Bolshevik government outlawed public expressions of antisemitism, making them legally punishable, ${ }^{15}$ while simultaneously launching a public campaign to address antisemitic stereotypes within society through the distribution of information pamphlets, theater performances, films, agitation sketches, and newspaper articles, among others.

In general, the state sought to build cohesion between Jews and non-Jews, and it did so in decisive yet delicate manner. It is interesting to note that the ferocious Soviet campaigns against religion were much more cautious when attacking Judaism, with officials carefully managing a delicate line between the fight against antisemitism and the fight against Jewish clericalism. As Anna Shternshis argues, because Soviet activists believed that antisemitism was a greater evil than religion, the Russian language antireligious materials were used not to criticize Judaism but to defend it, and even when ridiculing some of the Jewish religious holidays, these publications were careful to guard against too negative a portrayal so as not to provoke antisemitism. ${ }^{16}$ Without doubt, any religion (including Judaism) was castigated and portrayed as one of the foremost impediments of modern life and integration into Soviet society, but the unique approach the Soviets took towards Judaism in particular reflects their broader priority of combating antisemitism. ${ }^{17}$

11 Soviet propaganda made a concerted effort to show Jews in a new light, trying to demonstrate to society that, when given the possibility, the Jews were extremely successful in agriculture, industry and other fields, and made a serious contribution to the Soviet economy. A film entitled Seekers of Happiness was released in 1936 starring several prominent Yiddish-speaking actors and told the story of a Jewish family who moved from abroad to the USSR and found fulfillment and happiness by building the "Soviet Zion." 18 In a similar manner, however, Russian-language publications were cautious when touching sensitive issues. For example, they deliberately underrepresented the actual number of Jewish agricultural settlements, most probably "so as not to provoke an additional outburst of public antisemitism," given the conditions of competition for land resources. ${ }^{19}$

12 The Soviet fight against antisemitism encompassed a clearly formed set of policies which, if we use Jochen Hellbeck's terminology, represented a multitude of 
"subjectivizing practices." ${ }^{20}$ The regime, at least in the interwar period, continuously punished, derided, and ridiculed antisemites; explained and educated its non-Jewish citizens in order to dismantle negative stereotypes and prejudices against the Jews; and cultivated and promoted new positive images about the Jews as "normal," dignified, and devoted members of Soviet society. At a 1928 meeting of Party activists in Moscow, the topic of allegations that foster prejudice against Jews was discussed. These were addressed in forms of questions like: "Why it is that Jews do not want to do heavy work? How is it that Jews always manage to obtain good positions? Why were Jews in the Crimea given good land, whereas the land the Russians received is not as fertile?" ${ }^{11}$ Some of these issues were addressed at the highest official level, as shown by the publication of a brochure called "The Jewish question" by the president of the Supreme Soviet of the USSR, Mikhail Kalinin, in 1927. ${ }^{22}$ Lazar Kaganovich, one of the most influential members of the Politburo, did not restrain speaking Yiddish publicly when it fitted the propagandistic goals of the regime. ${ }^{23}$

13 Soviet nationality policy acquired new elements under Stalin, especially during the ideological shift that occurred in the late 1930s, which Nicholas Timasheff dubbed "the great retreat." ${ }^{24}$ Preoccupied with state-building and legitimacy, and eager to harness its population's patriotism for the pending war in Europe, the Soviet leadership started to include russocentric and statist themes in official party line, as internationalist ethos slowly faded away. This new line projected the ambitions of a great power, as well as the state's determination to defeat its numerous enemies, which, in Stalin's view, threatened socialism from all sides, within and without. ${ }^{25}$ The growing fear of disloyalty eventually led to ethnic cleansing and ethnic terror against the nationalities with suspect crossborder ethnic ties, but nation-building policies remained in place for the majority of non-stigmatized nationalities. ${ }^{26}$ In 1934, the creation of a Jewish Autonomous Region in the Far East, with its capital in Birobidzhan, marked the establishment of a territorial unit for Soviet Jews. At times, officials tended to gloss over antisemitism and went out of their way to proclaim solidarity among the Soviet Union's various ethnic groups, but nevertheless the occurrence of antisemitic acts was publicized and antisemitic behavior was vigorously prosecuted. Robert Weinberg's study reports, for example, that in 1935 a Russian machinist at a railway depot was sentenced to five years in prison for a series of nasty pranks he played on Jewish coworkers, and in 1937, two construction workers who had made antisemitic slurs in their dormitory were sentenced to two years in prison. ${ }^{27}$

The social and economic integration of Jewish life in the Soviet Union manifested itself in many ways, most obviously in a sharp rise of interethnic marriages. Both Jews and non-Jews, especially the younger generation, who were educated under the Soviet regime, were no longer attributing much importance to religious and ethnic differences and willingly embraced the idea of mixed marriages. Mordechai Altshuler provides evidence of a three-fold growth in the number of mixed marriages by 1939 in the USSR compared to the figures from the 1926 census. ${ }^{28}$ In Ukraine, the number of Jewish men married to non-Jewish women grew from 3.7 percent in 1924 to 18.1 percent in 1939, while the figure for Jewish women married to non-Jewish men went from 4.5 percent to 15.8 percent. ${ }^{29}$ In 1939, in the region of Odessa, about 229 out of every 1,000 marriages in the Jewish population were mixed marriages..$^{30}$ 


\section{Antisemitism on Soviet territories during the Second World War} occupied territories during the Second World War. In that respect, the gentile involvement in anti-Jewish violence in the aftermath of the 1941 Nazi invasion of the Soviet Union across a swath of territory stretching from roughly the Baltic to the Black Seas is particularly well documented..$^{31}$ Jan Gross has detailed fierce, voluntary antisemitic actions undertaken by Polish gentiles who organized a pogrom that destroyed Jewish life in the village of Jedwabne. ${ }^{32}$ An equally infamous pogrom occurred in the Ukrainian city of Lviv, where 7,000 to 10,000 Jews were murdered by locals upon the arrival of the German army ${ }^{33}$ According to a source of information, a Ukrainian youth confessed to having single-handedly slain 75 Jews in Lviv in one night. ${ }^{34}$ Vicious attacks against Jews took place in eastern Poland, Lithuania, western Ukraine, Bessarabia, and other regions that became part of the Soviet Union after the Molotov-Ribbentrop Pact of $1939 . .^{35}$ The territories that had experienced decades of Soviet power are notably absent from these accounts. Jewish populations towards the Jews on Soviet territories under Nazi rule. ${ }^{36} \mathrm{His}$ analysis, based on German Einsatzgruppen reports, suggests that regions that had been exposed to Soviet rule demonstrated lower levels of support for anti-Jewish activities when compared with neighboring territories of Eastern Europe that had not experienced such rule. Remarkably, the author does not make any suggestions regarding the causes of this difference. Barbara Epstein's work on the Minsk ghetto (Belarus), partially builds on Arad's observation by stressing the substantial, organized solidarity of gentiles with Jewish victims. ${ }^{37}$ Epstein explains this wartime solidarity through a number of factors, including "Soviet internationalism" constructed among the population prior to the war However, Epstein assumes that the Soviet regime did not have the same impact on Ukraine, were it was unable to eradicate the traditional antisemitism. ${ }^{38}$

New scholarship on the Holocaust in Ukraine has noted the fact that the population in central and southern Ukraine [part of the USSR during the interwar period], with few exceptions, refrained from anti-Jewish violence even when the Einsatzkommandos tried to incite it, while, in the Ukrainian regions of western Volhynia and eastern Galicia [part of Poland in the interwar years], by contrast, dozens of pogroms occurred in the summer of 1941, after the German invasion. ${ }^{39}$ Ray Brandon and Wendy Lower share Epstein's conviction that antisemitism had certainly not been eradicated by Soviet rule, but tend to underscore that the readiness to resort to anti-Jewish violence had clearly receded among this population. ${ }^{40}$

Comparably, Amir Weiner, who studied the Ukrainian region of Vinnitsa during the occupation, confirms that there was no popular antisemitic violence when the Nazi arrived, but points simultaneously to the survival of antisemitism among the local population. Although he admits that the evolution of ethnic Soviet policies in the decade before the German invasion left "an intriguing legacy," in his interpretation, more than anything else, it was the unprecedented scale and endurance of the genocide that shaped people's responses to the Jewish destruction by Nazis in former Soviet Ukraine. ${ }^{41}$

Yet other studies come to underline the rise of popular antisemitism during the Second World War both on the occupied territories and in the Soviet rear. For example, Gennady

Cahiers du monde russe, $52 / 1$ | 2011 
Kostyrchenko demonstrates that thousands of kilometers away from the frontline, antiJewish feelings arose from the "lethargic" condition they had taken under the dictatorship of Stalin, being resuscitated by the conditions of disorder, hardship, and the devastation of war. ${ }^{42}$ Altshuler has pointed out that in liberated Kiev many Jews returning from the Soviet interior encountered hostility, since gentile residents were forced to return apartments and other property to their original owners. Under these circumstances a number of antisemitic manifestations were reported..$^{43}$ Some letters of Soviet citizens collected by Ilya Ehrenburg during and after the Second World War contain similar indications of antisemitic attitudes in liberated areas of the USSR, including Odessa. ${ }^{44}$ In a broader sense, the authors Timothy Snyder, Kate Brown, and Doris Bergen note that one outcome of the Nazi occupation of the former Soviet territories was the revival of antisemitism and nationalism, leading to the escalation of ethnic conflict after the war. ${ }^{45}$

\section{Antisemitism in Odessa: From the late tsarist period into the Soviet Times}

\section{The pre-Soviet landscape}

20 The perception of Odessa in Imperial Russia had a specific character. Odessa's distinctiveness resulted from a blend of such factors as the city's strategic location on the Black Sea, its commercial raison d'être, a related consumer culture, its relative newness and self-conscious modernity, its vibrant mix of people - especially Jewish and Russian - and its criminal underworld. ${ }^{46}$ The city was also known for its relative affluence. It is not by accident that in the nineteenth century, the Jews from the city of Odessa came to be associated with a life of comfort and pleasure-seeking, as well as an indifference to religion, and this differentiated themselves significantly from Jews in the rest of Tsarist Russia. ${ }^{47}$ According to the 1897 census, the Jews formed Odessa's second largest group, or 34.41 percent of the population. Their number was only surpassed by Russians, who formed 45.58 percent, and was followed by Ukrainians (9.38 percent), Poles (4.29 percent), Germans (2.48 percent), and Greeks (1.26 percent). ${ }^{48}$

21 Contacts between Jews and non-Jews were quite frequent in this multinational city, but the two groups still succeeded in maintaining separate lives. Steven Zipperstein, for example, emphasizes that despite the tendency towards acculturation and the loosening of traditional restraints in Odessa towards the end of the nineteenth century, there was little relaxation of the social barriers separating Jews and non-Jews, and anti-Jewish sentiments intensified especially in universities and schools. ${ }^{49}$ The memoirs of Vladimir Zhabotinskii, a Jewish intellectual born in Odessa, are evocative and representative of this trend. While he affirms that all literate residents red the same newspapers and "thought about the same Russian problems," when referring to his school experience, he depicts an entrenched segregation:

Yet, at the same time we all lived in rigidly separated national groups, especially we Jews. Without any propaganda, without any ideology, we ten Jews used to sit on one row of benches in class, next to one another [...]. In the [1890s], even antisemitism drowsed - not, Heaven forbid, in the government, but in society. We were quite friendly with our Christian classmates, even intimate with them, but we lived apart and considered it a natural thing that could not be otherwise... The 
five Poles, I recall, used to sit always in the "Polish corner," like the three Greeks,

the three Armenians, and the two Moldavians in theirs. ${ }^{50}$ a significant role in fueling antisemitism. Like in many other places, the non-Jews of Odessa perceived Jews as parasitic members of society who made their living at the expense of non-Jews. Odessan Jews suffered periodic violent attacks. The pogroms of $1821,1859,1871,1881$, and 1905 left clear marks on the history of the Jewish-gentile relationships, and convinced many Jews that "Judeophobia was not a theoretical error of some kind but an attitude that reflected centuries upon centuries of hatred." 52 These pogroms led to hundreds of deaths at the hands of civilians. It also became common knowledge that in this period almost every sector of the Christian population contributed to the anti-Jewish agitation and took part in the pogroms, including Greek grain monopolists, wealthy Russian merchants, nationalist Ukrainian intellectuals, those associated with liberal professions, government administration, and the "barefoot." 53 Fearful for their lives and property, numerous Jews decided to emigrate during the turbulent beginning of the twentieth century. After the bloody pogrom of 1905, nearly fifty thousand Jews left Odessa. ${ }^{54}$ Anti-Jewish violence became especially lethal in Ukraine after the February revolution of 1917, but, fortunately, in Odessa a self-defense unit was created by ex-officers and soldiers of the Russian army and due to its existence no pogroms occurred in the city during the Civil War. ${ }^{55}$

\section{Odessa's Jews in the interwar period (1921-1941)}

The testimonies of Odessa's Jewish natives have helped us gain a unique insight into Jewish-gentile relationships in that city during the interwar and Second World War periods. As mentioned earlier, most of these materials belong to the Yad Vashem collection documenting the Holocaust: therefore, the description of these relations was not the goal of respondents' narratives, but it was frequently made in the form of tangential references which we had to carefully collect and assemble. Despite great differences in content, a number of recurrent themes and observations throughout the testimonies depict common experiences from that period.

There is, of course, a risk of bias in these stories, as with any personal testimony or recollection. However, the bias in this case, if any, should lean towards vilifying Soviet nationality policies since it came from Jews who emigrated from the Soviet Union during the Cold War, a time when Israel sided with the West and the Soviet Union prevented Jews from leaving its borders. It would also be difficult to imagine Soviet émigrés to Israel downplaying encountered antisemitism or violence. Therefore, if violence is unexpectedly low or if Soviet policies are described as particularly positive vis-à-vis behavior towards the Jews, this can be taken as a signal that Soviet policies had an enduring impact on interethnic relations in Odessa. However, one should also not 
disregard the possibility that Holocaust survivors could have a posteriori developed their positive views of the "world before" the catastrophe. To deal with the potential biases in the sources, we also triangulated whenever possible, using data from other archival and secondary sources. Finally, we remain methodologically indebted to other scholars who have worked closely with autobiographical texts. ${ }^{56}$

According to Odessa's Jews, the interwar policy of Jewish integration and the fight against antisemitism resulted in significant success. Unlike the historian Gennady Kostyrchenko's account, which considers that there has been some form of return of antisemitism after 1936, the memories of Odessan Jews tend to represent the entire interwar period as one uninterrupted phase of ethnic harmony ${ }^{57}$ Throughout numerous Jewish sources, a strong and clear message is apparent: the Jews experienced a friendly environment free of ethnic conflict. These sources went so far as to create the impression, at times, that there was no ethnic and national awareness among citizens in Odessa. ${ }^{58}$ Although the city preserved its heterogeneous ethnic and linguistic make-up (in 1926, about 39 percent of its population was Russian, 36.7 percent was Jewish, and 17.6 percent Ukrainian), ${ }^{59}$ the previous discourse of separation of the groups, as earlier described by Zhabotinskii, never came up in the testimonies of Odessans referring to the interwar period. The generation growing up in the 1920s gives striking images when describing its experience of "national" identity. One of those Odessans remembers that, while he was in school, "nobody ever talked about nationality; this question almost did not exist." One of his close friends was Armenian, another was Georgian, and the rest were Jews and Russians. He said that, in general, the children "did not distinguish by nationality"; moreover, they "did not have a clue what nationality [was]." ${ }^{60}$ A Jewish woman tells us that her best friend was a Ukrainian, but before the war they would not care to know each other's nationalities, because back then they "somehow were not interested in this. All people were the same"; the children only knew and cared that "this is Natasha, Vera, or Valya..." ${ }^{61}$

These are striking statements when compared with other mixed Jewish communities during the interwar period in other East European countries. For example, in neighboring Romania, a Jewish woman referring to the relationship between the Jewish and Romanian children in her school, noted that "we didn't befriend each other, well, we made friends, but not really." ${ }^{62}$ Another remembers how teachers encouraged Christian children to hit and beat Jewish children during recess. ${ }^{63}$ Similar accounts exist from across the region, but such comments are virtually absent from statements from Soviet Odessa, and that absence may extend to other areas of the Soviet Union.

The nationality issue seemed so meaningless and irrelevant to the young Jewish generation of Odessa that some were confused by the very concept. When one girl was asked in a school library about her nationality, she did not understand the question's meaning. ${ }^{64}$ In another situation, when a Jewish person could not understand being asked for identification with a group, the eventual answer was: "I am an Odessan." ${ }^{65}$ Many Jewish children went to Russian-language schools, although Yiddish-speaking schools functioned in the city as well. One of those former children fondly remembers her experience before the Second World War: "It was really good... very friendly. The people were good and kind. The Jews felt comfortable [evrei chuvstvovali sebia $\mathrm{v}$ svoei tarelke]." ${ }^{66}$ The overwhelming majority of Jewish respondents attest the absence of antisemitism in the interwar period. ${ }^{67}$ 

Tsarist Russia and the Soviet interwar period, who could compare the differences directly. Unfortunately, there are very few of those who gave testimonies on that topic. We managed to find six testimonies that made specific comparisons and they made even sharper declarations than the young that grew up during the interwar period. Mikhail Ghershoig, for example, juxtaposed the facts that before the revolution he was regarded as a "little Yid," but after that he "ceased being called a Yid" altogether. He remembered the 1920s as a golden age for Soviet Jewry, with no antisemitism and plenty of opportunities for Jews. This stood in stark contrast to the Tsarist period when the vast majority of Jews were geographically confined to the Pale of Settlement and prevented from working in most professions, the civil service, and other government posts. His most intense declarations reflect a profound feeling of acquired equality, the awareness of the fact that the Jews no longer felt like a "second-class people," the Jewish surprise and wonder at being "promoted everywhere," at "being valued," even "worshiped" (menia bogotvorili) under Soviet power. Although not a religious person himself, he was astounded by the fact that religious Jews could go to synagogues and "nobody would laugh or throw stones." ${ }^{8}$ Ghershoig was convinced that in the 1920s, all the Jews of the Soviet Union shared one common belief that the Jews "became [real] people" thanks to the Soviet regime. He conveyed the admiration and tremendous pride of being Jewish within these new conditions, that allowed entry to any university, the possibility to work in any location or profession, and especially the fact that nobody humiliated Jews publicly. To him, and many other Jews like him, Soviet power was described as "our power." ${ }^{69}$

Ilya Gherber, another Odessan who had known prerevolutionary times, was especially impressed by the lack of antisemitism at the university where, out of a group of 35 to 40 people, there were 12 Jews and "all were treated equally." ${ }^{70}$ A similar state of freedom, upward mobility, and lack of national discrimination was described by Genrikh Reider, a military academy's graduate student during the interwar period. Numerous Jews studied in his academy, but "during those times nobody paid much attention [to somebody's Jewish identity]." He describes the multicultural environment of the army, prosecutor's office, and tribunals, where many Jews worked together with different ethnic groups, like Tatars, Kazakhs, and Ukrainians. Reider describes individuals from different backgrounds joining together in their work without any contemplation, at least outwardly, on the issue of national belonging. ${ }^{71}$ Abram Feldman vividly remembers the feeling "of being a Jew" in a tsarist Russian school, but under the Soviet government he started "not to pay attention to it" and not to perceive it as an important identifying factor. ${ }^{72}$ During the Soviet period, when he graduated from the university, Feldman was among a few specialists selected for the marine fleet, and he was confident that the selection committee did not care about ethnic background as there were several Jewish people among those selected. ${ }^{73}$

31 The same opinion is shared by less educated Jews, such as Boris Pototsky, who, after completing seven classes of secondary school, decided to work in a factory. When speaking about the Russians during the interwar period and their attitude towards the Jews, he stresses that they were "very friendly" and that some "would not even have a notion of what a Jew was (ne imeli poniatiia, chto takoe evrei)."

We do not imply that during the interwar years, antisemitism was completely defeated, nor that life in the Soviet Union was idyllic, for Jews or anyone else. During the interwar 
period the Jews, as well as other nationalities, suffered as Soviet citizens from the inhumane collectivization, famine, and the infamous Great Terror. However, we want to stress that the Jewish people of Odessa experienced a significant improvement in their relationships with non-Jews, precisely because of the official policy described above. The younger people were socialized during the 1920s and 1930s in an environment that seemed to them relatively free of antisemitism. Official statistics also point to increasing integration of Jews in broader society. In 1926, the Jewish population of Odessa was 153,243 (36.7 percent) out of a total population of 420,862 , and there were 18,789 Jewish workers (27.7 percent), while 7,285 were white collar workers, 5,774 worked in the food industry, 4,354 in the medical branch, 2,317 were teachers, and 1,574 were artisans..$^{75}$ In 1934 in Odessa there were already 60,000 Jewish workers. ${ }^{76}$

Some other research also suggests a softening of antisemitic sentiment in Soviet Ukraine. After closely studying police reports (svodki), Andrei Marchukov, a specialist of the GPU, ${ }^{77}$ argues that during the 1920s antisemitism survived in Ukraine across all strata, although "in the majority of cases it had an indistinct character, taking acute forms only in fights for land." 78 However, he accepts that over time, as the country was overcoming the trauma of collectivization and the first Five-Year Plan, as people of various nationalities entered the echelons of power, as the Jews were assimilating, and as social, national, and religious differences between the people were diminishing, there was a narrowing of the ground which nourished anti-Semitism. ${ }^{79}$

\section{Odessa's Jews and non-Jews during the Second World War}

Those few studies that refer to Odessa under the Romanian occupation have sketched various cases of how the non-Jewish population acted towards the Jews during the occupation. According to one historian's assessment, the evidence of solidarity with Jews outweighs that which indicates hostile relations..$^{80}$ Concurrently, Alexander Dallin has underlined that the attitude of Odessa's population towards the Jewish destruction cannot be easily summarized, since there were enough examples of contradictory behavior and "it would be erroneous to deny the existence of antisemitism. It would be equally false to attribute to non-Jews any general jubilation over the Jews' fate." ${ }^{81}$

When Romanian and German troops entered Odessa on October 16, 1941, many of the city's Jews had already been evacuated deeper into the Soviet Union, but about 80,000 to 90,000 Jews $^{82}$ remained in the city, unable to leave due to the lack of transportation, disorder during the first months of the war on Soviet territory, and frequent enemy bombings of the Odessa harbor and departing trains. ${ }^{83}$

For younger Jews, the newly established Romanian rule's racist policies came as a profound shock. Seventeen-year old David Starodinskii was among numerous men of various nationalities arrested on the second day of occupation; he remembered how a Romanian soldier approached the column of men, looked at him and asked: "Jidan [Yid]?" Starodinskii wrote afterwards about his reaction:

This may look strange or maybe even funny, but at that time I did not understand the meaning of the question. I was raised in an environment where the nationality question never came up; I did not even know the nationality of my school mates.

He told the Romanian soldier that he did not understand. The soldier began repeating the question with ever-increasing irritation until somebody quietly explained to the 
young man that the soldier was asking about his ethnicity. When he learned the boy was Jewish, the soldier struck him violently and left. Starodinskii remembered this as his first "baptism," his "first class on the nationality question." ${ }^{4}$

\section{Absence of pogroms} - in particular, its spontaneous attacks against Jewish communities - represents "the litmus test of collaboration" for many scholars. ${ }^{85}$ We see this less as a test of collaboration than a broader litmus test of Jewish-gentile relations in a given region. From the beginning of the occupation in the East, Nazi allies disseminated a venomous anti-Jewish propaganda which blamed the Jews for the crimes of the Communist regime, depicted them as the dominant class in Soviet society, and accused them of causing the war. Jews were visibly singled out from the rest of the population: they were forced to clear rubble (in Odessa as well), became subject of retaliation for real or presumed acts of sabotage, and were forced to wear the yellow star, in preparation for their final isolation and extermination. ${ }^{86}$

There is suggestive evidence that both Romanian and German authorities overtly or secretly encouraged civilians to engage in anti-Jewish violence in territories which came under their control. Germans were proven to orchestrate several antisemitic 'retaliation' campaigns in occupied Ukraine. In those cases, Jewish men were forced to exhume the bodies of prisoners killed by the retreating Soviets, and sometimes to wash the corpses and dig the victims' graves. Meanwhile, the local population was allowed to vent its rage against the "Bolsheviks" by beating Jews with clubs and other available instruments. ${ }^{87}$ Moreover, Einsatzgruppen records reveal that mobile killing units were directly involved in inciting antisemitic attacks: when referring to the first months spent in the Soviet Ukraine, one report makes reference to Einsatzgruppen's deployed strategy of "persecut[ing] Jews [by] using the Ukrainian population" 88 and another mentions making "careful efforts" to bring about Jewish pogroms." 89

militaries were also inciting anti-Jewish violence - though we were not able to find documents referring directly to Transnistria, there is evidence of such "technique" deployed in neighboring Bessarabia. An order issued by the Romanian counterintelligence on July 8, 1941 required instigating acts of "spontaneous" antiJewish violence prior to the arrival of the army and gendarmerie. It proposed "to eliminate the Judaic element from the Bessarabian territory still under the Soviet government by organizing the teams moving ahead of the Romanian troops." ${ }^{90}$ The instructions divided the territory between three Romanian counterintelligence subdivisions, provided for the creation of "teams" from among the local inhabitants, and mapped out their itineraries. These teams were supposed to gather in the villages of NemŢeni, Răzeni, Tochilu, Leova, and Cania. Members of the teams had to be recruited from among loyal Bessarabians on the Romanian-controlled territories. Each team comprised two to four villagers, who were expected to spread "via relatives, acquaintances, and anticommunist elements the idea of collective defense against the Judaic danger [emphasis in the original]."

41 In order to facilitate recruitment, the document suggested appealing to the "Romanian feelings" of the population hostile to the Soviet regime, or alternatively seeking out those who had suffered under Soviet rule. It also encouraged making use of patriotic 
sentiment, gratifying certain wishes of the local population, and advancing specific activities within the national domain. ${ }^{92}$ Finally, the groups assembled were promised resources to cover their "maintenance and displacement" costs.

In relation to the order issued, Lieutenant Colonel of a counterintelligence unit Al. Ionescu reported that his unit had already launched the mission "to create an atmosphere unfavorable to Judaic elements in the villages so that the populace would seek to eliminate them by the means they may find best suited to the circumstances. By the time the Romanian troops arrive, the [appropriate] atmosphere will have to be already created and [the locals] should have proceeded with the actions." ${ }^{93}$ Although there are no further documents tracing the evolution of this "operation," Vladimir Solonari's study documents a number of deadly attacks in rural Bessarabia and Bukovina during the summer of $1941 .{ }^{94}$ Were they caused by Romanian provocateurs or were these 'spontaneous' manifestations? We will probably not be able to find a definite answer to this question. Clearly, in some areas the local population proved to be particularly susceptible to the Nazi message and manipulations, openly demonstrating that it shared a strong anti-Jewish attitude and was inclined to vent its antisemitism in a violent manner: in addition to the mentioned attacks in Bessarabia and Bukovina, a wave of pogroms began in the first days of occupation in Western Ukraine, Latvia, and Lithuania. 95

As for Odessa, existing information in both secondary sources and archival material does not suggest a mass unleashing of antisemitism during the Axis occupation. In fact, there is no evidence of any pogroms at all. The only 'mass' antisemitic incident of which we are aware, after extensive research on the city using primary and secondary sources, is reported in Dallin's book on Odessa. Dallin wrote about a group of "young hooligans" who, immediately after German planes dropped virulently antisemitic leaflets in the initial stage of the Romanian invasion, ran through the streets of one poorer section of Odessa shouting the old tsarist slogan "Beat/kill the Jews, save Russia! (Bei zhidov, spasai Rossiiu)." ${ }^{96}$

German intelligence was monitoring gentiles' attitude towards Jews and came to attest the lack of antisemitism among Odessans. A report submitted immediately after the capture of Odessa testifies that "during the first days the population [...] proceeded towards the Jews with relative loyalty." ${ }^{97}$ As late as the end of 1941, the absence of an ethnic divide among the local population was still noted as a predominant feature in the city. A German officer recorded at that time that the people of Odessa thought of themselves and their fellow-residents not in terms of ethnic categories but as part of a local community. ${ }^{98}$ This is consistent with the Einsatzgruppen reports mentioned at the start of this paper, which noted a difficulty in stirring up antisemitic violence in those territories that had been part of the Soviet Union since the 1920s. ${ }^{99}$

\section{State-led violence and persecution}

The new political and social environment of Odessa was suffused with antisemitic Nazi propaganda from the first days of occupation. Newspaper articles raved about racial purity, Jewish peril, Jews causing the war, and Hitler's antisemitic speeches. ${ }^{100}$ Shortly after the occupation of the city, Romanian authorities began to murder the local Jewish population. On October 22, 1941, a bomb exploded in the Romanian military headquarters, killing 61, including some high-ranking personnel. ${ }^{101}$ Cruel reprisals were 
ordered by the Romanian dictator Ion Antonescu against "communists" and "Jews." On the next day, General Constantin Trestioreanu reported: "I hanged in the public squares of Odessa about five thousand people, mostly Jews." ${ }^{102}$ In addition, about 19,000 Jews were gathered in the public square and shot; their bodies were sprayed with gasoline and burned. ${ }^{103}$ On October 24 , at least 16,000 Jews held in Odessa's jail were moved to the outskirts of Dal'nik and massacred in a similar manner: the soldiers locked the victims in several large barns and opened fire with machine guns; the buildings were then set on fire. ${ }^{104}$ The remaining $40,000 \mathrm{~J}$ ews were kept in the city under close surveillance.

Between October 1941 and January 1942, the Jews who survived the initial massacres were still living in the city, but were "marked like criminals with yellow six-pointed stars on their chests" and were exposed to possible mistreatment by anybody who would wish to offend or abuse the Jews. ${ }^{105}$ In January, the Romanian authorities issued a new order requiring the Jews to be moved to the ghetto of Slobodka, at the edge of the city. From there, the Jews were to be deported to other camps under Romanian administration. On January 11, 1942, the forced deportation of Jews from Odessa began.

A description of the situation by a then-schoolboy reveals the tragic setting:

On January 11, Anatoly (who was just getting over typhus), Mama, and I were forcibly taken to Slobodka. They took us and led us off at three in the morning. Temperatures were well below freezing. The snow was up to our knees. They drove us along in a crowd. Many people - the elderly and children - died right there in the streets of Peresyp (on the outskirts of the city) in a howling blizzard. ${ }^{106}$

A police report sent in those days to the Third Romanian army office describes the situation in Odessa, including the mood of the city's population. According to its statement, the non-Jewish population was calm and "the measures related to the internments of the Jews in the ghetto and their evacuation was received by the Christians favorably." It also mentions that the Jews were demoralized because of bad weather and that the evacuation was continuing without interruption. The same document states that "the overwhelming majority of Jews from ages 18 to 50 are hiding in the city or have run away from the city." ${ }^{107}$ It does not explain how was it possible for the majority of adult Jews to hide or to escape in a city where non-Jews approved of the Jews' internment and deportation.

The Romanian authorities continued to track down and deport the missing Jews. According to records on the deportation schedule, by February 22, 1942, a total of 20,792 Jews had been deported from Odessa to camps in Berezovka-Vasilievo. ${ }^{108}$ Another report by the Romanian military gives a different figure of 28,574 deported by February $15 ;{ }^{109}$ meanwhile, a later army report mentions 33,000 deportees. ${ }^{110}$ According to the estimation of one of Odessa's administrators, between 20 and 25 percent of the deportees died during the transportation itself, due to severely cold weather. ${ }^{111}$ Most of the surviving Jews were imprisoned in camps and were later murdered, in 1943, by an SS detachment.

\section{Criminal opportunism}

50 The phenomenon of opportunism and profiteering spread quickly in wartime Odessa. The city experienced an enormous increase in crime and near-criminal activities, including felonies of all kinds from drunkenness to murder. ${ }^{112}$ The city has been described as going through a "general decline of morals," with rising unemployment, and undisciplined 
youth engaging in acts of violence and vandalism. ${ }^{113}$ The abuse, naturally, was directed against the groups and individuals that happened to be in the weakest position, and which could be mistreated with the least danger for the profiteers. Greed and opportunity to plunder officially persecuted Jews undoubtedly sparked criminal behavior among some of Odessa's residents.

51 According to one Jewish report, during the first two months of occupation, some "dark little people, former criminals" began to appear. They would sport an armband with a swastika and rob apartments; there were cases of Jews being ousted from their apartments and the criminals moving in. ${ }^{114}$ One letter, written on July 4, 1944, provides a prominent example. A Ukrainian, Semën Beliavskii, married to a Jewish woman, wrote to his brother-in-law about his arrest during the first days of occupation. Beliavskii recalled how, after being released after a few days, he went straight to his relative's dacha (presumably outside Odessa), where the entire family gathered. Soon after, the daughter of the local gardener and several other women from the village brought Romanian soldiers to the family dacha claiming that the Beliavskiis were Jews. Semën denied the fact, insisting that he was Russian, but the women accused him of lying, and insisted that his passport must be fake. ${ }^{115}$ The Beliavskiis were taken to jail. When Semën came back to the dacha several days later, he found empty rooms, and his belongings had disappeared. ${ }^{116}$ In another letter, Semën specifies the name of the gardener's daughter, Pavlinka, as the one who robbed the house. ${ }^{117}$

52 Alla Kashkova, who grew up in the family of an engineer, gave us a relevant vignette. Before the war, the people from Alla's apartment building and courtyard were always very friendly, but she believes that "the Russian people for some reason always lived worse than the Jews." In her account, after the Soviet evacuation, many Odessans "started to change in front of our eyes." To her surprise, "some clothes, some chairs had more importance than the life of one's neighbors," and there were cases where Odessans entered apartments owned by Jews, or simply occupied them directly. ${ }^{118}$ After the war, the Soviet justice system had to intervene in a number of cases to oust profiteers from their neighbors' apartments. ${ }^{119}$ The Soviet state also intervened to force residents to return belongings stolen from Jews and others during the war. ${ }^{120}$

Both survivor testimonies and secondary sources indicate that there were many instances when gentiles reported the presence of hidden Jews to the authorities. The source of these denunciations largely remains unknown, but it almost certainly came from gentile neighbors. In a few situations the source was known. One survivor, for example, mentioned an incident when his sister was recognized in the street by a former neighbor, who immediately grabbed her hand and started to shout "Jew!" calling for the police. $^{121}$

54 It is almost impossible to determine patterns of participation in opportunistic thievery and betrayal, but there are some indicators. For example, a Soviet Jewish soldier returning to Odessa in 1944 tried to understand which Odessans treated the Jews poorly during the occupation, and he came to the conclusion that, essentially, they were "people of nonintellectual work...simple people, workers, little functionaries, especially on the peripheries." ${ }^{122}$ Similar conclusions can be found in numerous survivors' accounts. 123

55 According to victims, there was a specific group apparently involved in the betrayal and robbery of Jews. They were described as predominantly gardeners, caretakers, janitors (dvorniki), and other apartment building personnel. In one such documented case, a 
janitor caught two Jewish women and took them directly to the Romanian secret police. ${ }^{124}$ In another case, Klavdia Anisimova, who, together with her mother, hid a Jewish girl, remembers being especially scared of the janitor Dunya, who "was keeping the whole apartment building in terror" (derzhavshei $v$ strakhe ves' dvor) and to whom they would frequently bring gifts to avoid betrayal. ${ }^{125}$ These caretaker staff members are remembered by some Jewish survivors, in resonance with Stalinist times, as the "troika" of the building - the most hostile and dangerous to Odessa's Jews. There are several explanations as to why this group in particular might be implicated in the persecution of Jews. First, they were made responsible by the Romanian authorities for any "illegal activity" or unauthorized presence in the building. ${ }^{126}$ They were obliged by the occupying administration to report on any new or suspect resident, and, of course, on any returning Jewish inhabitants after their deportation. Moreover, some of the janitors and apartment building superintendents were replaced by informants of the Siguranţa (Romanian secret police) ${ }^{127}$ in order to prevent partisan activity and monitor resistance in Odessa. Yet other personal reasons could also have motivated the building staff's behavior as well. The prospect of material gain should not be underestimated, nor should envy of their better-off neighbors be disregarded as a possible motivation. In addition, some of these personnel could think they were just "doing their duty," or acting in such a manner mainly out of fear, following an antisemitic government's orders. Finally, compared to the rest of Odessa's population, this group consisted of an older and less educated people, meaning that they were less subject to the prewar Soviet state ideology and propaganda promoting interethnic harmony.

In general, whenever mentioning the mistreatment of Odessa's Jews, the victims refer to "hooligans," 128 "bandits," "robbers," and "scoundrels," 129 involved in this activity. The curious thing is that these terms are used even in cases with observable antisemitic features. Thus, in one case a Jewish woman remembered how a Russian "hooligan" drove her family by cart (probably being summoned by Romanians) to a designated ghetto and at the end of the trip, took her mother's belongings and slammed her on her back and said "Beat the Jews, save Russia!" 130 The terminology used by the Jews, when describing the abuse suffered in Odessa, has a separate message in itself: predominantly, it avoids placing occurred facts in an antisemitic frame, and intends to emphasize somehow the marginality of the encountered phenomena. In the case of the documentation collected for the Soviet Black Book, one may sensibly assume that included accounts were censored to fit the Soviet vision of collaboration. However, the fact that independent Jewish memories use a similar terminology indicates that either Soviet narrative of collaboration was internalized by Jewish survivors, or that the broader situation in wartime Odessa hindered Jewish perception of perpetrators' acts against the Jews as primarily antisemitic in their intention.

Acts of opportunism and abuse also occurred during the deportation of Odessa's Jews, including one of the most sordid forms of "trade." When huge columns of Jews were marched through the city, some locals would approach Romanian soldiers, offer between 2 and 3 German marks and say: "I want this coat" (presumably pointing to a Jew from the column). The soldier would approach the Jew and take his coat at gun point. ${ }^{131}$ Another account depicts the Jews' indignation at perpetrators who "suddenly appeared from nowhere, in our [Jews'] understanding a 'fifth column,' [who] imagined they could grab coats from women, and beat and rob men and children." ${ }^{132}$ In one case, during the boarding of the Jews of Odessa in freight cars at the train station in Slobodka, "a band of predators descend[ed] upon them from somewhere - teenage robbers [...] tearing baskets 
with their remaining provisions..." ${ }^{133}$ Nevertheless, one respondent, who provided part of this incriminating information, insisted on adding that

for the sake of truth it is worthwhile mentioning [that] a huge number of locals, when these crowds [convoys of Jews] were passing by, expressed condolences, but under the threat of repressions could not get involved. ${ }^{134}$

While the racial concept propagated by the new regime did not seem to gain much ground among former Soviet citizens, some individuals did adopt the Nazi idea that the Jews were to blame for the war's onset. One Jewish soldier, when returning to Odessa after the war, met a drunken man on a train who was shouting: "I will shoot you all, Yids, you Yids sold yourself to Hitler, and because of you millions of people were killed." ${ }^{135}$ The soldier attacked the drunkard and was assisted by passengers both in trying to reason with the drunkard and later justifying the soldier's actions in front of a Soviet policeman. This demonstrates the infiltration of at least some ideas promoted by fascist forces into the ideological circuit within the occupied territories.

\section{Gentile support for the Jewish population}

While acts of violence and opportunism were ever-present, there is much more to say about Jewish - non-Jewish relationships. As mentioned above, Odessa's Jews had been an integral part of the prewar Soviet social environment with frequent intermarriages, a shared Russian language, and meaningful connections with other ethnic groups. As a result, the Jews of Odessa were able to draw on their extensive social capital.

Schools were one of the main institutions that had forged friendly and genuine relationships. David Starodinskii, for example, was helped numerous times during the occupation by his classmate Liudmila, a Russian girl who courageously visited him, bringing food to the prison site where he was held together with other Jews. ${ }^{136}$ Boris Kalik was 12 years old when he lost his family in the evacuation and had to return to Odessa. He approached a school friend's Russian family and, despite having three children of their own, the family agreed to take him in. According to Kalik, the family treated him well and "whatever they would eat" he "would eat the same." ${ }^{137}$ However, after it became extremely dangerous to have Jews in the house, Kalik sensed his protectors' concern (although they never mentioned it to him), and volunteered to go to the site where all Jews were collected. The family walked him to the destination point and visited him afterwards to bring him food..$^{138}$

61 Many non-Jews agreed to hide Jews in their houses in the winter of 1942. Thus, Villi Perkenwald and his mother were sheltered for longer than one month by a woman they had not previously met; the woman was described as just "a decent person." Without question, this woman was terrified by the frequent searches conducted by the Romanians, and in those cases she would simply leave the house to the Jewish family and pretend she was not the owner. ${ }^{139}$ During that entire month, Villi's mother went frequently to her former flat and took belongings which she had previously given away to neighbors. ${ }^{140}$ Other survivors also mentioned leaving their belongings with neighbors and returning periodically during the war to take items and exchange them for food. ${ }^{141}$

One particular case stands out as evidence of a durable bond that had developed during the interwar years. Originally from Odessa, in 1933 Rita Dubovaya's family moved to the village of Ghershunovka. When the war started and the family attempted to evacuate further inland, they left all their animals and belongings to one of their Moldovan 
neighbors. The evacuation failed because of the quick advance of Nazi troops, and the family ended up in the Rybnitsa ghetto, not far from Ghershunovka. During the entire period of their internment, the Moldovans would come every week-end to bring food and other goods to the Jewish family in the ghetto. Rita mentions that other neighbors from Ghershunovka also helped out in various ways, by, for example, collecting money for them until "ours [the Soviet army] arrived." It is the help of those neighbors, according to Rita, that insured the Jewish family's survival. ${ }^{142}$

Throughout all the testimonies and secondary sources we read, we could not find any pattern or distinction between how a person treated Jews based on their ethnic identity. Even at the height of the Holocaust, when Nazi policies were promoting ethnic Germans and destroying ethnic Jews, one Jewish survivor remembers his apartment building as a relatively safe place with benevolent ethnic German neighbors: the German family name, Meers, even acted "as some kind of protection." Meanwhile, an ethnic Romanian family, the Androniks, who had lived there for decades, were also described as doing a lot to help their Jewish neighbors. ${ }^{143} \mathrm{~A}$ recent study by Eric Steinhart indicates that the ethnic German assistants to SS personnel, while hired to help to identify the city's true Volksdeutsche, helped their Odessan fellows by providing false translations, vouching for others' credentials, and indicating loopholes that aided in saving Jewish lives. ${ }^{144}$

People from various social strata, with different religious beliefs and educational backgrounds were also identified as helping Odessa's Jewish residents during the war. Some were good friends or acquaintances, but many had not had any previous contact with the people they helped. The account of Iakov Manevici who, in January 1942, managed to run away from a death camp in Bogdanovka and return to Odessa is exemplary in this sense. The teenager, who had returned to the city seriously ill, was hidden from flat to flat by "sensible people," including Christians, peasants, and by "progressively thinking people [...] Komsomol [a Communist youth organization], Party groups." He emphasizes that the latter were not necessarily partisan groups, but just "groups of people involved in the resistance, and therefore helping out those who needed help." When remaining in Odessa became impossible, it was the fishers who helped Manevici get out of the city and run towards safer territory. ${ }^{145}$

Liuba Baraevskaia was a child when, together with her mother, she was arrested and moved to the Slobodka ghetto. Her mother's ethnic Russian acquaintance offered to bring her own daughter's passport to allow the Jewish girl to sneak out of the camp and bring goods from their house. When the Jews of Slobodka were moved elsewhere, Liuba managed to escape with the help of a random Russian boy, and she was sheltered by an unknown Russian woman. Liuba spent seven months hiding in Odessa, until she ended up in an orphanage, where it was not known that she was Jewish. ${ }^{146}$

66 In their testimonies, Jewish Odessans remember many people who hid them during the war, even if for only one night. The Russian Ivan Polishchuk, with the help of his friends, dug an underground shelter in the heart of the city and, for two years, hid 16 Jewish families there. A Ukrainian engineer, Leonid Suvorovsky, with the assistance of friends, put up 22 Jewish families, selling his own clothes and trading cigarettes in order to provide them with food. ${ }^{147}$ These gentiles risked their own and their children's lives by hiding Jews; as many Jews were quick to point out, those families could be killed if caught. ${ }^{148}$ In the best-case scenario, if caught, the non-Jews would end up in jail, which is what happened to Alexandra Volovtseva and her mother. In August 1942 the two women, who were hiding a Jewish man, were arrested after a police raid; they managed to help 
the man escape from a police house, but they were beaten and tortured in the Romanian gendarmerie. ${ }^{149}$

Occasionally, some of Odessa's Jews were saved thanks to another risky form of support: their non-Jewish acquaintances had to step forward and falsely testify to Romanian authorities about the "non-Jewishness" of the arrested persons. This happened to Olga Kantorovich, a young Jewish woman saved by a caretaker in her house and another friend, both Russian women. ${ }^{150}$ Others helped to forge passports for their Jewish friends and acquaintances. ${ }^{151}$

The report of a Jew who went into hiding during the occupation of Odessa mentions "very frequently" encountering people who knew about his Jewishness, but who "forgot" about it when they met him. These facts were also perceived as "a form of help." ${ }^{152}$ If Jewish people were identified as Jews to the authorities, they would of course be immediately rounded up and sent to ghettos or other death camps. Anna Morgulis, who lived for half a year with a false passport in Odessa's workers' district of Moldavanka, concurred: "Lots of Russians knew or suspected that I was a Jew [...] but no one turned me in. This was how I survived." 153 One curious account involves the ethnic Russian Averichev family. The father and his sons, all sailors, were remembered by a Jewish neighbor as occasionally getting drunk in the years before the war and shouting the tsarist slogan "Beat the Jews, save Russia!" However, when "the dark and difficult time came about," the same Jewish neighbor attested to the fact that the family risked their own lives to save Jews from persecution. ${ }^{154}$

One clear pattern that emerges from the testimonies is that the youth was definitely perceived by the Jewish population as the most trustworthy category of society. It is towards them that the persecuted Jews could and would express "moral demands," expecting them to "serve the ideals" shared by members of Soviet society. ${ }^{155}$ Scholarly research agrees that, in general, "pro-Communism appears to have been more deeply rooted in the younger age group; this was especially true at the university." ${ }^{156}$ Some of the Jewish survivors openly admitted having strong faith "in the fairness of the fight against fascist occupiers" and "in the ideals" in which they were raised within the Soviet Union. These Jews also testified to the fact that the non-Jewish youth also shared these values even in the most difficult periods. For example, when arrested, many non-Jews would not denounce Jews, since "the arrest of a Russian [non-Jewish] boy would leave him the possibility to defend himself, to give some explanations," meanwhile the capture of a Jew simply meant death." ${ }^{157}$ Alexandr Sepino, another Odessan, ended up believing that "in that time all our [Soviet] youth were patriotic." 158

Odessa's intelligentsia was another group which proved to be relatively immune to the newly propagated antisemitism. In Dallin's view, "antisemitism was apparently least active in intellectual circles." ${ }^{159}$ An incident related to Molva, one of the most widely circulated newspapers in Transnistria, provides a relevant example. ${ }^{160}$ Printed from December 1941, it had the reputation of a professional newspaper, leaning towards the Governor's office. ${ }^{161}$ One of Molva's staff started to write a series of pamphlets with a virulently antisemitic character. These articles were described as having "produced unanimous hostility at least among the intelligentsia" and several contributors protested against them. The Russian editor of the newspaper accepted that the pieces were "abominable," but that the occupying authorities insisted on their publication. Several contemporaries concurred that the paper's antisemitic nature afterwards led to a drop in circulation. ${ }^{162}$ 
71 It is estimated that in 1944, a few thousand Jews were still living in Odessa, some of them under false documents, some hiding in catacombs, other sheltered by non-Jewish families. ${ }^{163}$ The minority who survived the deadliest camps of Transnistria, managed to stay alive only because they would sneak out, beg in villages, and receive aid from locals. 164

\section{Conclusion}

72 Nineteenth-century Odessa was known as a city where local Jewry acculturated to the gentile culture with a special verve. Nevertheless, this phenomenon did not remove existent social barriers between its Jews and Christians, nor did it impede violent pogroms erupting sporadically in the city. Soviet power tried to override this inherited antisemitism and launched a sound set of measures intended to integrate its Jews effectively and create new, positive connections between these two historically acrimonious groups. Odessa went through a radical change in its environment during those interwar years: Jewish accounts provide strong evidence of a particularly friendly ambiance and a significant decline in antisemitism.

During the period of Romanian rule, the Soviet "friendship of the peoples" was put to a severe test, with the gentile population given the opportunity and even encouragement to victimize the Jewish population. Unlike Jews living in other areas of Central and Eastern Europe where this opportunity was seized upon by large swaths of the nonJewish population who engaged in violent pogroms and antisemitic violence, the Jews of Odessa did not suffer mass violence at the hands of non-Jewish inhabitants. During the war, the Jewish population of Odessa continued to be perceived by gentile residents as city fellows, even if proscribed by the new regime. In the light of available data it seems likely that the youth, intelligentsia, and other members of society had internalized, at least partially, the values endorsed by the Soviet regime. Thus, inhabitants from various social strata and national backgrounds showed wartime solidarity with Jewish victims, and displayed a reserved attitude towards the hierarchical racial system introduced by the Romanian and German authorities. As noted, there was a group of Odessans involved in denunciation, abuse, and persecution of their Jewish and non-Jewish neighbors, perhaps because of responsibilities assigned by occupational authorities or due to personal greed and feelings of hostility. We speculated, based on limited evidence, that those people tended to be older and with lower educational backgrounds, which would have made them potentially less subject to Soviet ideology. More research needs to be conducted in this area.

74 Yitzhak Arad's article, which we mentioned earlier, concludes that in the regions that had experienced 23 years of Soviet rule, "the local people generally related to the Jews with greater restraint and less overt manifestations of hatred" than in the territories acquired by the USSR in 1940.165 Odessa's case fits that pattern and consolidates Arad's line of argument. Accordingly, relations between the Jews and non-Jews in World War II Odessa resembled more the ones in Belarus's Minsk than those in West Ukraine's Lviv. Arguably, this case study indicates that despite the long history of antisemitism in Odessa, the Soviet policy of national amalgamation had somewhat been internalized by the city's residents. Soviet prewar socialization and integration appear to have had an impact not only on the outward behavior of its citizens, but also on the mutual perceptions of ethnic categories. 


\section{NOTES}

1. Richard Pipes, The Formation of the Soviet Union: Communism and Nationalism, 1917-1923, rev. ed. (Cambridge, MA: Harvard University Press, 1997); Robert Conquest, ed., The Last Empire: Nationality and Soviet Future (Stanford: Hoover Press Publication, 1986); Olaf Caroe, Soviet Empire: The Turks of Central Asia and Stalinism, 2nd ed. (London: Macmillan, 1967).

2. Terry Martin, The Affirmative Action Empire: Nations and Nationalism in the Soviet Union, 1923-1939 (Ithaca: Cornell University Press, 2001); Francine Hirsch, Empire of Nations: Ethnographic Knowledge and the Making of the Soviet Union (Ithaca: Cornell University Press, 2005). See also Juliette Cadiot, Le laboratoire impérial: Russie-Urss, 1860-1940,(P.: CNRS Edtions, 2007).

3. On the transformative side of national policy see Douglas Northrop, Veiled Empire: Gender and Power in Stalinist Central Asia (Ithaca: Cornell University Press, 2004); Adrienne Edgar, Tribal Nation: The Making of Soviet Turkmenistan (Princeton: Princeton University Press 2004); Jeremy Smith, The Bolsheviks and the National Question, 1917-1923 (Basingstoke: Macmillan, 1999).

4. One of the few exceptions is Rasma Karklins' Ethnic Relations in the USSR: The Perspective from Below (Boston: Allen \& Unwin, 1986), which was based on a survey undertaken in 1979 with 200 Soviet German émigrés to West Germany. Karklins concludes that his respondents at that time "predominantly feel that the overall ethnic climate is bad. There are, however, several factors mitigating against overt demonstrations of ethnic disenchantment, the most of which is the Soviet political control system with all its facets, including press campaigns and resulting social 'double-think.' People understand that ethnic strife is officially taboo, as a result, tend to suppress feelings or to express them in less tangible and anonymous ways," 72-73.

5. During the 1930s, Soviet officials put special emphasis on "the friendship of peoples" discourse in an attempt to bolster the unity among ethnic nations. The propaganda referred to "the brotherly union" of nationalities or spoke about the "eleven sisters" of the Soviet family. For a detailed analysis of the development of the Soviet concept of "the friendship of peoples" by Soviet historiography, see Lowell Tillett, The Great Friendship: Soviet Historians on the Non-Russian Nationalities (Chapel Hill: University of North Carolina Press, 1969).

6. Martin based his conclusion on the analysis of a survey conducted between 1950 and 1951 by Harvard Interview Project which employed several hundred Soviet citizens that moved to the United States following the Second World War. He mentions that many respondents directly linked the absence of popular ethnic prejudice and conflict to official state policy. Martin, Affirmative Action Empire, 388, 392.

7. See David L. Hoffman, Stalinist Values: The Cultural Norms of Soviet Modernity, 1917-1941 (Ithaca: Cornell University Press, London, 2003), 79.

8. Pogroms took place there in $1821,1859,1871,1881$, and 1905. See Steven J. Zipperstein, The Jews of Odessa: A Cultural History, 1794-1881 (Stanford: Stanford University Press, 1985); Robert Weinberg, The Revolution of 1905 in Odessa: Blood on the Steps (Bloomington: Indiana University Press, 1993), 165-188; Robert Weinberg, "Workers, Pogroms, and the 1905 Revolution in Odessa," The Russian Review, 46 (1987): 53-75; Shlomo Lambroza, “The 
Tsarist Government and the Pogroms of 1903-1906," Modern Judaism, 7, 3 (Oct. 1987): 287-296.

9. Estimates are between 302 deaths to over 1,000. See Robert Weinberg, "Workers," 2, note 2. The figure of 1,000 Jewish victims is given by the Soviet editors of Sergey Witte's memoirs - S. Iu. Vitte, Vospominaniia, vol. 3 (M., 1960), 615. Meanwhile, 47 Jews were killed in Kishinëv in 1903, while 29 were killed in 1905 in Zhitomir, and close to 100 were killed in Kiev in 1905. See Gur Alroey, "Bureaucracy, Agents, and Swindlers: The Hardship of Jewish Emigration from the Pale of Settlement in the Early 20th Century," in Ezra Mendelsohn, ed., Jews and the State: Dangerous Alliances and the Perils of Privilege (Oxford: Oxford University Press, 2003), 215.

10. These interview materials are preserved in Yad Vashem Archives in Record Group 0. 3: "Collections of Testimonies" and Record Group 0.33: "Collection of Testimonies, Memoirs and Diaries."

11. See an analysis of the policy regarding the Jewish question by Zvi Y. Gitelman, Jewish Nationality and Soviet Politics (Princeton: Princeton University Press, 1972).

12. A relevant example is the book of Apollon Karelin, Zlye rosskazni pro evreev [Pernicious Stories about the Jews]. Published in Moscow in 1919, it tries to tear down negative stereotypes about Jews, including the blood libel, by explaining in popular language that the bourgeoisie deliberately provoked hatred among people and used Jews as scapegoats - cited in Anna Shternshis, Soviet and Kosher: Jewish Popular Culture in the Soviet Union, 1923-1939 (Bloomington - Indianapolis: Indiana University Press, 2006), 153.

13. Rocky L. Rockett, Ethnic Nationalities in the Soviet Union: Sociological Perspectives on a Historical Problem (New York: Praeger, 1981), 99.

14. Ibid.

15. Avrahm Yarmolinsky, The Jews and other Nationalities under the Soviets (New York: Vanguard Press cop., 1928), 115.

16. Shternshis, Soviet and Kosher, 150, 153, 154.

17. See for example the story "Babushka v brake" [Grandmother in a marriage] described in Shternshis' work. It depicts the story of a mixed marriage of a young couple of communists in which two grandmothers got involved after a baby's birth. Outraged by the disrespect shown towards religious tradition by the parents, the Christian family secretly baptized the boy, and the Jewish relatives undertook a secret circumcision. The baby caught a cold during the baptism and got injured from the circumcision; he died at the end of the story. Shternshis, Soviet and Kosher, 151.

18. Robert Weinberg, Stalin's Forgotten Zion: Birobidzhan and the Making of a Soviet Jewish Homeland: An Illustrated History, 1928-1996 (Berkeley: University of California Press, 1998), 32-33.

19. Ibid., 160 .

20. Hellbeck argues that the Bolsheviks were pursuing a quintessentially modern policy of subjectivization, of fostering conscious citizens who would become engaged in the program of building socialism on their own will. He considers that the success of this effort was guaranteed through political agitation, educational policies, re-educational measures and others. Jochen Hellbeck, "Working, Struggling, Becoming: Stalin-Era Autobiographical Texts," Russian Review, 60, 3 (2001): 342.

21. Shternshis, Soviet and Kosher, 159-163. 
22. Ibid., 159.

23. Lazar Kaganovich, one of Stalin's close allies, worked his way to first secretary of the Communist Party in the Ukraine (1926-1928), and supervised Soviet transport and industry during the 1930s. He was among the few Jews who managed to stay in the highest ranks of the party and state, even during Stalin's antisemitic purge at the beginning of the 1950s. In 1936, Kaganovich and other party officials gave speeches partly in Yiddish at a party conference in Birobidzhan. Weinberg, Stalin's Forgotten Zion, 62.

24. Nicholas Timasheff, The Great Retreat: The Growth and Decline of Communism in Russia (New York: E. P. Dutton \& Co., 1946).

25. David Shearer, "Elements Near and Alien: Passportization, Policing, and Identity in the Stalinist State, 1932-1952," The Journal of Modern History 76, 4 (Dec., 2004): 841; David L. Brandenberger and A.M. Dubrovsky, “The People Need a Tsar': The Emergence of National Bolshevism as Stalinist Ideology, 1931-1941," Europe-Asia Studies 50, 5 (1998): 882-883.

26. Terry Martin, "The Origins of Soviet Ethnic Cleansing," Journal of Modern History, 70, 4 (1998): 816-817; Timothy Snyder, Bloodlands: Europe between Hitler and Stalin (New York: Basic Books, 2010).

27. Weinberg, Stalin's Forgotten Zion, 66.

28. Mordechai Altshuler, Soviet Jewry on the Eve of the Holocaust: A Social and Demographic Profile (Jerusalem: Yad Vashem, 1998), 75.

29. Ibid., 74.

30. Ibid., 76.

31. Kopstein and Wittenberg compiled in their study a pogrom data base for Poland which included 37 pogroms across 231 localities. See Jeffrey Kopstein and Jason Wittenberg, "Deadly Communities: Local Political Milieus and the Persecution of Jews in Occupied Poland," Comparative Political Studies, 44, 3 (March 2011): 259-293.

32. Jan T. Gross, Neighbors: The Destruction of the Jewish Community in Jedwabne, Poland (Princeton: Princeton University Press, 2001).

33. Omer Bartov, "White Spaces and Black Holes: Eastern Galicia's Past and Present," in Ray Brandon and Wendy Lower, eds., The Shoah in Ukraine: History, Testimony, Memorialization (Bloomington - Indianapolis: Indiana University Press, 2008), 322.

34. Philip Friedman, "Ukrainian-Jewish Relations during the Occupation," in Ana J. Friedman, ed., Roads to Extinction: Essays on the Holocaust (New York, Philadelphia: Jewish Publication Society of America, 1980), 191.

35. Karen Sutton, The Massacre of the Jews of Lithuania (Jerusalem: GEFEN Publishing House, 2008); Wolfgang Benz and Marion Neiss, eds., Judenmord in Litauen: Studien und Dokumente (Berlin: Metropol, 1999); Vladimir Solonari, "Patterns of Violence: The Local Population and the Mass Murder of Jews in Bessarabia and Northern Bukovina, JulyAugust 1941," Kritika "Exploration in Russian and Eurasian History," 8, 4 (Fall 2007): 749-787.

36. Yitzhak Arad, "The Local Population in the German-Occupied Territories of the Soviet Union and its Attitude toward the Murder of the Jews," in D. Bankier and I. Gutman, eds., Nazi Europe and the Final Solution (Jerusalem: Yad Vashem, 2003).

37. Barbara Epstein, The Minsk Ghetto, 1941-1943. Jewish Resistance and Soviet Internationalism (Berkeley: University of California Press, 2008). 
38. Ibid., 42-43.

39. Brandon and Lower, eds., Introduction, The Shoah in Ukraine, 14.

40. Ibid.

41. Amir Weiner, Making Sense of War: The Second World War and the Fate of Bolshevik Revolution (Princeton: Princeton University Press, 2001), 271-275. As Weiner concludes, the majority of individuals on this territory were forced by the circumstances "to weight their greed and resentment [against Jews] against the trauma of living in the midst of an ongoing genocide."

42. Gennadii Kostyrchenko, Tainaia politika Stalina: Vlast' $i$ antisemitism (M.: Mezhdunarodnye otnosheniia, 2001), 242.

43. Mordechai Altshuler, "Antisemitism in Ukraine towards the End of the Second World War," Jews in Eastern Europe, 3, 22 (Winter 1993): 47.

44. Mordechai Altshuler, Yitshak Arad, Shmuel Krakowski, eds., Soviet Jews Write to Ilya Ehrenburg, 1943-1966 (Jerusalem: Yad Vashem, 1993). See for example letter no. 9, p. 140-142.

45. See for example Timothy Snyder, “To Resolve the Ukrainian Problem Once and for All': The Ethnic Cleansing of Ukrainians in Poland, 1943-1947," Journal of Cold War Studies, 1, 2 (1999): 91-92; Kate Brown, A Biography of No Place: From Ethnic Borderland to Soviet Heartland (Cambridge, London: Harvard University Press, 2004), 224. Doris Bergen, “The Nazi Concept of 'Volksdeutsche' and the Exacerbation of Anti-Semitism in Eastern Europe, 1939-1945," Journal of Contemporary History, 29, 4 (Oct. 1994): 572.

46. See more on the imperial history of Odessa in Patricia Herlihy, Odessa: A History, 1794-1914 (Cambridge, 1991). For a Soviet postwar cultural history of Odessa, see Maurice Friedberg, How Things Were Done in Odessa: Cultural and Intellectual Pursuits in a Soviet City (Boulder - San Francisco - Oxford: Westview Press, 1991).

47. Steven J. Zipperstein, The Jews of Odessa: A Cultural History, 1794-1881 (Stanford: Stanford University Press, 1985), 1.

48. M. Polishchuk, ed., Evrei Rossii i Novorossii. Sotsial'no-politicheskaia istoriia evreev Odessy $i$ drughikh gorodov Novorossii, 1881-1904 (M.: Mosty kul'tury, 2002), 344.

49. Zipperstein, The Jews of Odessa, 134.

50. Cited in Herlihy, Odessa: A History, 1794-1914, 255.

51. Ibid., 319-320; the data is for the year 1881.

52. Zipperstein, The Jews of Odessa, 127.

53. Encyclopedia Judaica, 2nd ed., vol. 15 (New York, 2007), s.v. “Odessa.”

54. Herlihy, Odessa: A History, 1794-1914, 258.

55. Encyclopedia Judaica, vol. 15, p. 380.

56. Marie-Françoise Chanfrault Duchet, "Narrative Structures, Social Models, and Symbolic Representations in the Live Story," in Sherna Berger Gluck and Daphne Patai, eds., Women's Words: The Feminist Practice of Oral History (London: Routledge, 1991), 77-91; Jean Peneff, "Myths in live stories," in R. Samuel and R. Thompson, eds., The Myths we Live by (New York - London: Routledge, 1990), 36-45; Marianne R. Kamp, "Three Lives of Saodat: Communist, Uzbek, Survivor," The Oral History Review, 28, 2 (2001): 21-58; Hellbeck, “Working, Struggling, Becoming: Stalin-Era Autobiographical Texts." 
57. Kostyrchenko argues that during the years 1917-1935, the Soviet state predominantly favored Jews and sponsored the development of Yiddish culture and a moderate acculturation; but after 1936, once it embarked upon the policy of "russocentric" assimilation, some elements of antisemitism started to penetrate the top of the power. See Gennady Kostyrchenko, Stalin protiv "kosmopolitov": Vlast' i evreiskaia intelligentsiia $v$ SSSR (M.: ROSSPEN, 2010), 68-69.

58. Dina Agopian, Interview 41342, University of Southern California (USC) Shoah Foundation Institute (1998); Emil' Al'perin, Interview 31580, USC Shoah Foundation Institute (1997); Vera Bakhmutskaia, Interview 44637, USC Shoah Foundation Institute (1998); Mal'vina Bakman, Interview 31666, USC Shoah Foundation Institute (1997).

59. Tanya Richardson, Kaleidoscopic Odessa: History and Place in Contemporary Ukraine (Toronto: University of Toronto Press, 2008), 32. The Soviet census of 1939 was classified and there are no available data, except information on the Jewish population (30.9 percent) provided by Mordechai Altshuler, Soviet Jewry on the Eve of the Holocaust, 40. Tanya Richardson estimates that by 1939 there had been a small increase in the proportion of Ukrainians living in Odessa.

60. Yad Vashem Archives (YVA), 0.3/5171, interview with Alexandr Sepino (1988), p. 1.

61. Vera Bakhmutskaia, Interview 44637, USC Shoah Foundation Institute (1998).

62. "[Deti] ne druzhili... druzhili, no ne ochen'," YVA, 0.3/11639, p. 44.

63. United States Holocaust Memorial Museum (USHMM), RG-50.572, Oral History, Moldova, interview with Andrei Vulpe (2008).

64. Mal'vina Bakman, Interview 31666, USC Shoah Foundation Institute (1997).

65. Emil' Al'perin, Interview 31580, USC Shoah Foundation Institute (1997).

66. YVA, $0.3 / 5229$, interview with Sofia Katz (1989), p. 1.

67. See for example YVA, 0.3/3954, interview with Dina Aizenberg (1975), p. 1; Vera Bakhmutskaia, Interview 44637, USC Shoah Foundation Institute; Bela Bakshanskaia, Interview 49761, USC Shoah Foundation Institute.

68. YVA, $0.3 / 5168$, interview with Mikhail Ghershoig (1988), p. 8.

69. Ibid., p. 9.

70. YVA, $0.3 / 5910$, interview with Ilya Gherber (1990), p. 2.

71. YVA, $0.3 / 5908$, interview with Genrikh Reider (1990), p. 5.

72. YVA, $0.3 / 5837$, interview with Abram Feldman (1989), p. 2.

73. Ibid., p. 3.

74. YVA, 0.3/6016, interview with Boris Pototsky (1990), p. 9.

75. Encyclopedia Judaica, vol.15, 378.

76. Ibid., 381. In 1939, Jews already numbered 200,981 out of 604,217 residents (33 percent).

77. These also included a close monitoring of antisemitic expressions.

78. Andrei Marchukov, Ukrainskoe natsional'noe dvizhenie. SSSR. 1920-1930e gody. Tseli, metody, rezul'taty [The Ukrainian National Movement. The USSR. The twenties and thirties. Goals, Methods, and Results] (M.: Nauka, 2006), 195.

79. Ibid., 195-196.

80. Dora Litani, "The Destruction of the Jews of Odessa in the Light of Romanian Documents," Yad Vashem Studies, 6 (1967): 148-149. 
81. Alexander Dallin, Odessa, 1941-1944: A Case Study of Soviet Territory under Foreign Rule (Iasi, Oxford, Portland, 1998), 209.

82. Litani, "The Destruction of the Jews of Odessa," 137.

83. YVA, $0.3 / 5177$, interview with Boris Kalik (1988), p.1; YVA, $0.3 / 5178$, interview with Sura Sturmak (1988), p. 3; YVA, 0.3/6054, interview with Alexandr Bakman (n.d.), p. 2.

84. David Starodinskii, Odesskoe getto: Vospominaniia [The Odessa ghetto. Memories] (Odessa: TPP Khaitekh, 1991).

85. Martin Dean, "Local Collaboration in the Holocaust in Eastern Europe," in Dan Stone, ed., The Historiography of the Holocaust (New York: Palgrave Macmillan, 2004), 121.

86. For more details on Romanian anti-Jewish policy in Transnistria and GermanRomanian relationships on this matter, see Andrej Angrick, "The Escalation of GermanRomanian Anti-Jewish Policy after the Attack on the Soviet Union," Yad Vashem Studies, 26 (1998): 203-238. See also Jean Ancel, Transnistria, 1941-1942. The Romanian Mass Murder Campaigns, 3 vols (Tel Aviv: The Goldstein Goren Diaspora Research Center, 2003).

87. Shimon Redlich, Together and Apart in Brzezany: Poles, Jews and Ukrainians, 1919-1945 (Bloomington: Indiana University Press, 2002), 101-102. See also Omer Bartov, "White Spaces and Black Holes: Eastern Galicia's Past and Present," in Brandon and Lower, eds., The Shoah in Ukraine, 318-353.

88. Karel Berkhoff, Harvest of Despair: Life and Death in Ukraine under Nazi Rule (Cambridge, MA - London: The Belknap Press of Harvard University Press, 2004), p. 73.

89. The same source complained that unlike in eastern Galicia [part of prewar Poland] these efforts "unfortunately have not produced the hoped-for success." Berkhoff, Harvest of Despair, 73.

90. General Staff of the Romanian Army, Plan of the Elimination of Judaic Element from the Bessarabian Territory under Soviet Control by Organizing Teams which will Advance before the Romanian Troops, USHMM, RG-25.003M/781.

91. Ibid.

92. Ibid.

93. Ibid.

94. Vladimir Solonari, "Patterns of Violence."

95. Arad, "The Local Population in the German-Occupied Territories," 235.

96. Dallin, Odessa, 1941-1944, 53. The same information is reported in Litani, "The Destruction of the Jews of Odessa," 148.

97. Dallin, Odessa, 1941-1944, 210.

98. Ibid., 194.

99. Arad, "The Local Population in the German-Occupied Territories," 236, 237.

100. Joshua Rubenstein and Ilya Altman, eds., The Unknown Black Book: The Holocaust in German-Occupied Soviet Territories (Bloomington - Indianapolis: Indiana University Press, 2008), The Recollections of Dr. Lidia Maximovna Slipchenko (Kozman), 110.

101. Radu Ioanid, The Holocaust in Romania: The Destruction of Jews and Gypsies under the Antonescu Regime, 1940-1944 (Chicago: Ivan R. Dee, 2000), 178.

102. Ioanid, The Holocaust in Romania, 179. General Ion Iacobici, commander of the Fourth Army, in the same evening of October 23 informed Antonescu's cabinet that "a number of 
Jews and Communists were hanged in reprisal" (USHMM/Marele Stat Major, RG 25.003M, roll 12 (203), fond Armata a IVa, vol. 870.

103. These figures are provided by the report of Colonel Rodler, chief representative of the Abwehr in Romania, cited in Raul Hilberg, The Destruction of European Jews, vol. 1 (New York: Holmes \& Meier, 1985), 306.

104. Litani, "The Destruction of the Jews of Odessa," 139. The numbers of victims, however, varies between sources. For example, German Colonel Rodler mentioned in his report 40,000 Jews killed in Dal'nik, quote from Ottmar Traşcă, Dennis Deletant, eds., Al III -lea Reich şi Holocaustul din România. 1940-1944. Documente din arhivele germane [The Third Reich and the Holocaust in Romania. 1940-1944. Documents from German Archives] (Bucarest: Editura Institutului NaŢional pentru Studierea Holocaustului din România "Elie Wiesel", 2007), 354. At the war crimes trial of Romanian war criminals, 25,000 to 30,000 victims were claimed in Dal'nik (Ioanid, The Holocaust in Romania, 182). Dennis Deletant writes about a total number of 15,000-20,000 Jews killed in October 1941 in reprisal for the blowing up of the Romanian headquarters: Dennis Deletant, "Transnistria and the Romanian solution to the "Jewish problem," in Ray Brendon and Wendy Lower, eds., The Shoah in Ukraine, 157.

105. The Unknown Black Book, The recollection of Dr. Lidia Maximovna Slipchenko (Kozman), 111.

106. Ibid., The recollection and verses of the schoolboy Lev Rozhnetsky, April 4-August 16, 1944, 125.

107. A.I. Kruglov, ed., Sbornik dokumentov i materialov ob unichtozhenii natsistami evreev Ukrainy v 1941-1944 godakh [Collection of Documents and Materials about the Destruction of Jews by the Nazis in Ukraine between 1941and 1944] (Kiev, 2002), 431.

108. USHMM/SRI (Romanian Intelligence Service Archives), RG 25.004M, roll 20, f. 40011, vol. 8; Ancel, Documents concerning the Fate of Romanian Jewry, vol. 5, 261, 263-264; Matatias Carp, Cartea neagră. Suferinţele evreilor din România. 1940-1944 [The Black Book. The Suffering of Jews from Romania. 1940-1944], 2nd ed., (Bucharest: Diogene, 1996) vol.3, 205, 225, 227; Ioanid, The Holocaust in Romania, 209.

109. Ioanid, The Holocaust in Romania, 210.

110. Ibid.

111. Carp, Cartea neagră vol. 3, 285-286.

112. Dallin, Odessa, 1941-1944, 137.

113. Ibid., 138 .

114. Ibid., 174; The Unknown Black Book, 111.

115. YVA, O.33/2560, letter of Semën Vasilevich Beliavskii from July 4, 1944.

116. Ibid.

117. YVA, $0.33 / 2560$, letter of Semën Vasilevich Beliavskii from July $1,1944$.

118. YVA, $0.3 / 5164$, interview with Alla Kashkova (1988), p. 4.

119. YVA, 0.3/5178. In her interview (1988), Sura Sturmak remembers meeting the prosecutor for her case, a man without a hand, "all [covered] in medals," apparently a war veteran. The legal process did not seem too long or sophisticated: the prosecutor summoned the woman who occupied the apartment illegally and "told her immediately to vacate the apartment," p. 14. 
120. YVA, $0.3 / 5164$, interview with Alla Kashkova (1988), p. 17.

121. YVA, Righteous Among Nations, File 7693, testimony of Yakov Goremaner.

122. YVA, O.3/5168, interview with Mikhail Ghershoig (1988), p. 16. YVA, Righteous Among Nations, File 7034; YVA, Righteous Among Nations, File 8558. Rakhil Yakover, interviewed by Diana Dumitru, January 2006, Washington, D.C.

123. YVA, O.3/6054, interview with Alexandr Bakman (1990), p. 3.

124. YVA, Righteous Among Nations, File 8558.

125. YVA, Righteous Among Nations, File 8390. See the testimony of Klavdia Anisimova.

126. Yakov Babenko, Interview 33874, USC Shoah Foundation Institute. See also the testimony of Krenia Sternberg, who emphasized how difficult it was for a janitor [dvornik] to help a Jew, since policemen, patrols, and others state employees visited and checked them out every day. YVA, Righteous Among Nations, File 4328.

127. Dallin, Odessa, 1941-1944, 76.

128. A Jewish boy also told about being "surrounded by a crowd of hooligans" while escaping to the village of Sirotskoe, $125 \mathrm{~km}$ from Odessa. They "yanked" his hat and dragged him back to the place where other Jews were kept. The Unknown Black Book, 126.

129. Ibid., 111.

130. YVA, 0.3/5165, interview with Rita Dubovaya (1988), p. 3.

131. YVA, O.3/5171, interview with Alexandr Sepino (1988), p. 34; YVA, 0.3/5178 interview with Sura Sturmak (1988), p. 6.

132. YVA, O.3/7592, interview with Iakov Manevici (1994), p. 4.

133. The Unknown Black Book, The Recollections of Dr. Lidia Maximovna Slipchenko (Kozman), 113.

134. YVA, O.3/7592, interview with Iakov Manevici (1994), p. 10.

135. YVA, O.3/5168, interview with Mikhail Ghershoig (1988), p. 14.

136. Starodinskii, Odesskoe getto, 18, 22.

137. YVA, $0.3 / 5177$, interview with Boris Kalik (1988), p. 2.

138. Ibid. See also the case of Rita Litvinova, who was helped by her former Russian schoolmate - YVA, Righteous Among Nations, File 6523. Viktoriia Vul'fin's family was sheltered by the family of Polina Kaputenko, Viktoria's classmate - YVA, Righteous Among Nations, File 7624.

139. YVA, 0.3/7593, interview with Villi Perkenwald (1994), p. 4.

140. Ibid., p. 5.

141. Interview with Lola Traxenberg, January 18, 2008, Washington D.C.

142. YVA, $0.3 / 5165$, interview with Rita Dubovaya (1988), p. 4, 6.

143. YVA, O.3/7592, interview with Iakov Manevici (1994), p. 19.

144. Eric Steinhart, "Policing the Boundaries of 'Germandom' in the East: SS Ethnic German Policy and Odessa's 'Volksdeutsche,' 1941-1944," Central European History, 43 (2010) 102-3.

145. Ibid., 13, 18.

146. YVA, O.33/4413, Interview with Liuba Baraevskaia (1986), p. 3, 6, 13.

147. Litani, “The Destruction of the Jews of Odessa," 149. 
148. YVA, $0.3 / 7592$, interview with Iakov Manevici (1994), p. 20-21; Starodinskii, Odesskoe getto, 14 .

149. The Unknown Black Book, Testimony of nurse Alexandra Yakovlevna Volovtseva, 119-120.

150. YVA, 02/467, Testimony of Raymond Arthur Davis (an American journalist), written in 1944 after the Soviets returned to Odessa, p. 6.

151. YVA, 02/467, Testimony of Raymond Arthur Davis, 1944, p. 2, 3.

152. YVA, $0.3 / 7592$, interview with Iakov Manevici (1994), p. 19.

153. The Unknown Black Book, The Story of Anna Morgulis from Odessa, 118.

154. YVA, O.3/7592, interview with Iakov Manevici (1994), p. 21.

155. Ibid.

156. Dallin, Odessa, 1941-1944, 123. The same opinion is expressed by Olga Kucherenko, "Reluctant Traitors: the Politics of Survival in Romanian-Occupied Odessa," European Review of History: Revue européenne d'histoire, 15, 2 (2008), 150.

157. YVA, $0.3 / 7592$, interview with Iakov Manevici (1994), p. 21-22.

158. YVA, $0.3 / 5171$, interview with Alexandr Sepino (1988), p. 4.

159. Dallin, Odessa, 1941-1944, 210.

160. Not to be confused with actual Transnistria, the separatist region of the Republic of Moldova. We refer to the territory between the Dniester and Bug rivers which was under Romanian administration between 1941 and 1944, and was named Transnistria by the occupying regime.

161. Dallin, Odessa, 1941-1944, 153.

162. Ibid., 154.

163. Encyclopedia Judaica, vol. 15, 381. Dora Litani estimates that even after the deportations from Odessa, about 10,000 Jews remained in the city hiding. See Litani, "The Destruction of the Jews of Odessa," 150.

164. Diana Dumitru, "The Attitude of the Non-Jewish Population of Bessarabia and Transnistria towards the Jews during the Holocaust: A Survivor's Perspective," Yad Vashem Studies, 37, 1, (2009): 53-83.

\section{RÉSUMÉS}

Résumé

L'article tente d'évaluer dans quelle mesure, au cours des vingt-cinq premières années d'existence de l'URSS, la population soviétique a intégré les politiques de 186 résumés l'état basées spécifiquement sur les relations interethniques. En choisissant Odessa comme objet d'étude, ce travail apprécie comment, par le biais de sa politique des nationalités, l'Union soviétique a géré l'antisémitisme, haine des plus anciennes et des plus intenses nourrie sur son territoire. Il retrace l'évolution des relations entre juifs et non juifs à Odessa depuis la fin de la période impériale en passant par les années de la domination soviétique jusqu'à l'occupation 
roumaine et allemande de la ville pendant la Seconde Guerre mondiale et présente les changements dramatiques qui survinrent dans les opinions et les comportements des résidents odessites, résultat premier de la socialisation sous le régime soviétique. La période de l'occupation roumaine permet de tester les «réalisations » soviétiques potentielles en ce qui concerne le combat de l'État contre l'antisémitisme dans la mesure où la Roumanie participait à l'Holocauste et encourageait la population non juive à trahir ses voisins juifs. La présente étude fait appel aux travaux de recherche existants sur la politique soviétique des nationalités, elle contribue à éclairer certains aspects de cette politique restés obscurs jusqu'à ce jour et, aussi, à faciliter la compréhension des mécanismes responsables de l'absorption des normes et des idées promues par l'État.

Abstract

This article evaluates the degree to which the Soviet population internalized state policies during the USSR's first 25 years of existence, focusing specifically on interethnic relations. Concentrating on the case study of Odessa, this research assesses how Soviet nationality policies dealt with one of the oldest and most intense animosities inherited on its territory: antisemitism. By tracing the evolution of the relationship between Jews and gentiles within Odessa starting in the late imperial period, then moving to the years of Soviet rule, and finally through the Romanian and German occupation of the city during World War II, the article exposes the dramatic changes which occurred in the viewpoints and attitudes of Odessa' residents, primarily as a result of socialization under the Soviet regime. The period of Romanian occupation is used to test potential Soviet "achievements" vis-à-vis its fight against antisemitism, since Romania participated in the Holocaust and encouraged the gentile population to betray its neighboring Jews. The present study engages existing scholarship on Soviet nationality policies, helping to illuminate aspects of this policy that have, so far, remained obscure while simultaneously assisting our understanding of mechanisms responsible for the absorption of norms and ideas promoted by the state.

\section{AUTEUR}

\section{DIANA DUMITRU}

World History Department Moldova State Pedagogical University 